\title{
Porcine prolactin receptor genotypes and production and reproduction traits in Hungarian Large White and Landrace sows (Brief Report)
}

\author{
Porcines Prolaktionrezeptor (PRLR) Genotypen und \\ Produktions- und Reproduktionseigenschaften bei Ungarischen \\ Large White und Landrasse Sauen (Brief Report)
}

\begin{abstract}
KATALIN KOVACS ${ }^{1}$, LASZLO FESUS ${ }^{1}$, ATTILA ZSOLNAI', ANDRAS NYIRI ${ }^{2}$ and ISTVAN ANTON ${ }^{1}$
\end{abstract}

${ }^{1}$ Research Institute for Animal Breeding and Nutrition, Herceghalom, Hungary, ${ }^{2} \mathrm{HUNGAPIG}$ Co., Herceghalom, Hungary

\section{Background}

Prolactin is an anterior pituitary hormone involved in many endocrine activities and plays and essential role in reproduction. Its receptor (PRLR) was detected in various tissues including brain, ovary, placenta, an uterus in several mammalian species (BOLE-FEYSOT et al. 1998). Reproductive performance of sows is a crutial point in pig production with significant economic importance and may be estimated with the help of markers. Porcine prolactin receptor gene is said to be a candidate genetic marker for reproductive traits. It has been mapped to porcine chromosome 16 (VINCENT et al. 1997). There is a C/G SNP in PRLR gene (KMIEC et al. 2001) at the position of 203 (GAN: U96306) which eliminates an Alul cleavage site. The effect of this polymorphism on litter size in various breeds has been estimated (VINCENT et al. 1998, ROTHSCHILD et al. 1998, VAN RENS et al. 2002, KMIEC and TERMAN, 2004, DRÖGEMÜLLER et al. 2001, KORWIN-KOSSAKOWSKA et al. 2003). The influence of the bovine hormone variant was also estimated (RATNA-KUMARI et al. 2008). The aim of the study was to estimate PRLR Alul polymorphism effects on litter size in Hungarian Large White (HLW) and Hungarian Landrace (HL) breeds.

\section{Procedures}

$202 \mathrm{HLW}$ and $71 \mathrm{HL}$ sows and $412 \mathrm{HL}$ piglets (offsprings of the $71 \mathrm{HL}$ sows) were included in this experiment. Primer sequences were as follows:

PRLR-F: 5'- CCC AAA ACA GCA GGA GGA CG-3' and

PRLR-R: 5'- GGC AAG TGG TTG AAA ATG GA-3'.

Primers were designed to amplify a $457 \mathrm{bp}$ fragment using DNA sequence of porcine PRLR gene (GenBank acc. no. U96306). PCR reactions were performed in a total volume of $10 \mu \mathrm{l}$, containing $200 \mu \mathrm{M}$ of each dNTP, $0.2 \mu \mathrm{M}$ primers, $10 \times$ PCR buffer, 0.5 unit Dynazyme DNA polymerase and $100 \mathrm{ng}$ genomic DNA. The PCR cycling profile consisted of denaturation at $94^{\circ} \mathrm{C}$ for $2 \mathrm{~min}, 35 \mathrm{cycles}$ of denaturation at $94^{\circ} \mathrm{C}$ (for $30 \mathrm{~s}$ ), annealing at $58^{\circ} \mathrm{C}$ (for $1 \mathrm{~min}$ ), and extension at $72^{\circ} \mathrm{C}$ (for $1 \mathrm{~min}$ ), followed by a final extension at $72^{\circ} \mathrm{C}$ for $3 \mathrm{~min}$ (after KMIEC et al. 
2001). Digested fragments (by Alul endonuclease) were resolved in $4 \%$ agarose gel stained with ethidium bromide and visualised under UV light. Genotypes were determined based on the fragment lengths such as: 125, 91, 79, 77, 66 and $19 \mathrm{bp}$ for $C$ allele and 125, 110, 79, 77 and $66 \mathrm{bp}$ for T allele. Genotypes and reproduction performance (total number of born piglets (TNB), number of piglets born alive (NBA) and number of weaned piglets (NWP)) of HLW and $\mathrm{HL}$ sows were recorded. Live weight data of piglets at the 1st and 21st days in HL breed were also collected. Allele frequency and population balance were examined in the population. Method of univariate and multivariate analysis of variance and estimated marginal means were used to estimate relationship between the locus and reproduction data of HLW sows. Whereas method of non-parametric measure of correlation was applied (due to deviation from normal distribution) in case of HL piglets.

\section{Results}

Allele frequency data (HLW: C: 0.38 , G: 0.62 ; HL: C: $0.5 \mathrm{G}: 0.5$ ) were similar to the results of KMIEC and TERMAN (2004) in case of HLW breed and to the findings of KMIEC et al (2001) and DRÖGEMÜLLER et al. (2001) in HL pigs. The calculated $x^{2}$ values did not indicate HardyWeinberg equilibrium in the populations. All studied traits showed significant changes between genotypes. Total number of born piglets (TNB) and piglets born alive (NBA) presented the highest value in $\mathrm{CC}$ genotype group. Significant differencies $(P<0.05)$ could be detected between CC, CG and GG genotypes in the results of TNB and NBA. (TERMAN 2005, KMIEC and TERMAN 2004). GG sows had the highest number of weaned piglets, but this advantage was not proved to be significant. However difference between CC and CG genotypes in NWP was significant $(P<0.05)$ for the benefit of $C G$ group.

There was significant difference from normal distribution in database of litter size (including TNB, NBA and NWP) of HL breed. Data could not be normalised due to its nature. Therefore non-parametric tests were used, such as rank transformation. Friedman test was applied as a non-parametric probe. There was significant difference $(P<0.05)$ between genotype groups in TNB and NBA, however verifiable difference could not be found in case of NWP. Litter size results showed normal distribution. So the methods of univariate analysis of variance and estimated marginal means were allowed to use. The effect of PRLR locus was only significant $(P<0.05)$ in case of 21st day live weight data, however live weight at birth was not influenced by this locus significantly. Although sex of piglet was a significant factor $(P<0.05)$ in weight at birth. Impact of fathers was strongly significant $(P<0.05)$ in both traits, indicating the importance of a number of loci inherited from the father and affecting live weight gain. As the result of Fisher LSD test, least square differences could only be found between genotypes in case of 21st day live weight. CG genotype group had the highest results and 21st day weight data of this genotype were significantly $(P<0.05)$ higher comparing to the similar data of $C C$ and $\mathrm{GG}$ genotype piglets. This outcome may reflect to the feed conversion and utilization capacity of piglets and their grow capacity and certainly to the maternal ability of sows.

In conclusion it can be said that porcine prolactin receptor locus may be linked indirectly to loci responsible for the control of reproductive performance of sows and live weight gain of piglets. Litter size traits of sows, as it was presented above, had a correlation to PRLR Alul 
polymorphism in both HLW and HL breeds. CC genotype resulted always the most beneficial one for litter size results. If 21st live weight is considered, CG genotype was seemed to achieve the best data.

\section{References}

Bole-Feysot, C, Goffin V, Edery M, Binart N, Kelly PA, (1998) Prolactin (PRL) and its receptor: actions, signal transduction pathways and phenotypes observed in PRL receptor knock out mice. Endocrinol Rev 19, 225-68

Drögemüller C, Hamann H, Distl O (2001) Candidate gene markers for litter size in different German pig lines. J Anim Sci 79, 2565-70

Kmiec M, Dybus A, Terman A, (2001) Prolactin receptor gene polymorphism and its association with litter size in Polish Landrace. Arch Tierz 44, 547-51

Kmiec M, Terman A (2004) Polymorphism in the PRLR/Alul gene and its effect on litter size in Large White sows. Anim Sci Papers Rep 22, 523-7

Korwin-Kossakowska A, Kamyczek M, Cieslak D, Pierzchala M, Kuryl J (2003) Candidate gene markers for reproductive traits 990 pig line. J Anim Breed Genet 120, 181-91 [in Polish]

Ratna Kumari A, Singh KM, Soni KJ, Patel RK, Chauhan JB, Sambasiva Rao Krs (2008) Genotyping of the polymorphism within exon 3 of prolactin gene in various dairy breeds by PCR RFLP. Arch Tierz 51, 298-99

Rothschild MF, Vincent AL, Tuggle CK, Evans G, Short TH, Southwood OI, Wales R, Plastow GS (1998) A mutation in the prolactin gene is associated with increased litter size in pigs. Anim Genet Suppl 1, 60-74

Terman A (2005) Effect of the polymorphism of prolactin receptor (PRLR) and leptin (LEP) genes on litter size pigs. J. Anim. Breed. Genet. 122, 400-4 [in Polish]

Van Rens, BT, Evans GJ, Van Der Lende T (2003) Components of litter size in gilts with different prolactin receptor genotypes. Theriogenology 59, 915-26

Van Rens BT, Van Der Lende T (2002) Litter size and piglet traits of gilts with different prolactin receptor genotypes. Theriogenology 57, 883-93

Vincent A, Wang L, Tuggle CK, Rothschild MF (1998) Linkage and physical mapping of prolactin to porcine chromosome 7. Anim Genet 29, 27-9

Vincent AL, Wang L, Tuggle CK, Robic A, Rothschild MF (1997) Prolactin receptor maps to pig chromosome 16. Mamm Genome 8, 793-4

Corresponding author:

KATALIN KOVÁCS

email: kovacs.katalin@atk.hu

Research Institute for Animal Breeding and Nutrition, Gesztenyés út 1, H-2053 Herceghalom, Hungary 